\title{
The State and the Rise of a Continuous Popular Educational Sphere in Sweden c. 1870s-1910s
}

\begin{abstract}
Anne Berg
Abstract

The age of imperialism, from the 1870s to the 1910s, saw the rise of a popular educational sphere in Sweden as well as in the rest of Europe. This sphere was characterised by an incomparable institutional growth and continuity. In earlier research, the growth of popular education has often been explained as a consequence of class-politics and the formation of a civil society. In this article I argue that another explanatory factor needs to be inserted in the overall historical narrative in Sweden, namely the material pre-conditions of the organisations that rose to stability and especially the economic grants offered by the industrial state. In fact, this study shows how the growth of the sphere and state grants to institutions such as folk high schools and lecture-societies went hand in hand. Furthermore it is shown how the share of public funding from the central bureaucracy as well as the local institutions of government successively became the dominant sources of income for folk high schools and lecture-societies. Thus, the article argues that the economic role of the state was a crucial factor for the rise of a continuous popular educational sphere.
\end{abstract}

Keywords

Sweden, nineteenth century, popular education, economic conditions, government grants, industrial state

\section{Introduction}

The major intellectual development of the years from 1875 to 1914 was the massive advance of popular education and self-education and of a popular reading public. In fact, self-education and self-improvement was one of the major functions of the new working-class movements and one of the major attractions for its militants. ${ }^{1}$

In his seminal work on The Age of Empires, Eric J. Hobsbawm emphasised the importance of the development of self-education amongst the working and middle classes in Europe during this era. In educational societies, workers institutes and especially the new working class movements, ordinary men and women absorbed the ideology of progress and emancipation, scientific and civic knowledge, learned the ropes of democracy and sometimes even the principles of socialism.

\section{Eric Hobsbawm, The Age of Empire 1875-1914 (New York: Vintage Books, 1989), 263.}

This article was written as a part of the research project The financing of Swedish popular education, 1872-1991: Economic governance, standards and practices between the public and voluntary sectors, funded by Handelsbankens forskningsstiftelser.

Anne Berg has a PhD in History and is Senior Lecturer in Pedagogy at the Department of Education, Uppsala University, Sweden.

Email:anne.berg@edu.uu.se 
What are henceforth referred to as popular education (folkbildning) were education practices characterised by its non-formal, non-meritocratic and voluntary character, taking place during leisure time. ${ }^{2}$ In the older territorial states in the West, popular education was mainly a part of social movements' attempts to reform the political system. ${ }^{3}$ In Eastern and Central Europe, the same type of education was a vital part of nationalist movement's mobilisation for self-determination and a state of their own. ${ }^{4}$ In the following I am especially going to focus on the West European or Swedish experience, but it is important to recognise that popular education has fulfilled different functions in different societal contexts.

In my view, the history of popular education can be regarded as a historical process from temporality, discontinuity and insecurity to steadiness, continuity and the forming of a real sector or sphere. I call this historical development 'the rise of a continuous popular educational sphere'. The origins of popular education can be traced to early modern Europe. During this period the lower nobility, tradesmen, capitalists, officials, priests, journalists and doctors founded patriotic periodicals and civic educational associations, clubs and movements, inspired by the enlightenment and later the romantic movements. ${ }^{5}$ Learning or bildung on the premise of voluntarism can be regarded as an important element in the making of a European middle class, and its ideological battle against the old absolutist monarchs and the high nobility. Self-education became a method, perhaps the method, for non-violent political action.

As a political phenomenon, popular education has often been interpreted as emancipatory actions for and by the repressed and marginalised. The first traces of this can be found around the decades of the revolutions of 1848 when popular education became a political tool in the hands of the workers, the artisans and the lower middle classes. During this period, the tendency was that radical organisations popped up and lived sporadic and rather uncertain lives. Movements were often kept alive by certain charismatic gentleman leaders and through the direct engagement of the members. ${ }^{6}$ Furthermore, the degree of involvement varied between different cities and parishes because of the decentralised nature of the organisations. One famous English example is the ephemeral Grand National Consolidated Trades Union, founded by the socialist Robert Owen, which never developed into a large cross-country union, which was the intention. The reasons were in part the lack of great national mobilisation. The 'restorated' governments also played a role in circumscribing or-

2 Popular education is a problematic concept to apply objectively in this sense, but I have, in loss of a better term, chosen to use it to encircle the object of study.

3 Tom Steele, Knowledge is power! The Rise and Fall of European Popular Educational Movements, 1848-1939 (Bern: Peter Lang, 2007), 41-66.

4 Miroslav Hroch, Social Preconditions of National Revival in Europe: A Comparative Analysis of the Social Composition of Patriotic Groups among the Smaller European Nations (New York: Columbia University Press, 2000[1985]), 8-10; Steele (2007), 15-17, 36-38, 43, 241-78.

5 In the case of Sweden, see especially Lars Petterson, Frihet, jämlikhet, egendom och Bentham: Utvecklingslinjer i svensk folkundervisning mellan feodalism och kapitalism, 1809-1860 (Uppsala: Uppsala universitet, 1992), ch. 6; Anne Berg, Kampen om befolkningen: Den svenska nationsformeringens utveckling och sociopolitiska förutsättningar ca 1780-1860 (Uppsala: Uppsala universitet, 2011), ch. 3-5.

6 James Vernon, Politics and the People: A Study in English Political Culture, c. 1815-1867 (Cambridge: Cambridge University Press, 1993), 257-60. 
ganisations. In France the most radical and republican movements, such as the Société des droits de l'homme, was wrecked by oppressive law-making in $1835 .^{7}$

The history of Swedish popular education harbours many examples of these tendencies. The first Swedish popular organisations were the so-called educational circles (bildningscirklar), established in the year 1845. The circles were educational and political movements which aimed to enlighten the urban-dwelling artisans. All in all thirty educational circles were founded in Sweden but they only survived a few years at a time. ${ }^{8}$ The decentralised workers association before the 1880 's also suffered from the lack of national unity, which in part explains their fluctuating success. Also in Sweden, the government tried to suppress educational organisations with radical and communist agendas.

While uncertainty and discontinuity was the overall pattern in the decades that surrounded 1848, the beginning of the 1870 s and onwards saw the emergence of popular educational movements and institutions characterised by steadiness, stability and incomparable numerical growth. University extension, worker's institutes, worker's associations, temperance movement's and 'popular movements' spread over Europe. In this historical phase, which Eric Hobsbawm discussed above, the rural areas and their lower classes were included as well. Although the urban milieus and the working class population continued to be important, the folk high schools in Denmark and Sweden are examples of this rural development. ${ }^{9}$

As I mentioned above, and as the brief sketch illustrates, the historical development of popular education from the 1870 s and onwards can be interpreted as a rise of a continuous popular educational sphere. Now the question at hand is of course how this rise can be explained? Why did this sphere arise and grow in Sweden during the period stretching from the 1870 s to the First World War?

The main argument in this article is that the state's economic role in the development is a previously overlooked explanation to why a continuous popular educational sphere emerged in the late nineteenth and early twentieth centuries. As I will try to show, the launching of a state-grants system was a crucial factor and material condition for 'the rise'.

The history of popular education is closely tied to the history of political, economic and social modernisation. ${ }^{10}$ When scholars have painted a picture of the rise and the historical development from discontinuity to continuity they have highlighted certain conditions, actors and explanatory mechanisms. The most predominate historical explanation consists of a chain of causal events which can all be connected to the process of industrialisation and especially its social consequences. Popular education has often been analysed as one of a range of institutions for the political awakening of the masses from the late nineteenth century and forwards. Thus, class struggle and class politics has often been the main explanatory mechanisms. In the well-argued synthesis Knowledge is Power! The Rise and Fall of European Popular

7 Ronald Amnizade, Ballots and Barricades: Class Formation and Republican Politics in France, 18301871 (Princeton: Princeton University Press, 1993), 29.

8 Berg (2011), ch. 7.

9 Steele (2007), 189-95

10 The question of why movement's rise in the first place has been one of the principal questions in this field of study during the last decades. See e.g., J. Craig Jenkins, "Resource Mobilization Theory and the Study of Social Movements," Annual Review of Sociology 9 (1983), 527-53. 
Educational Movements, 1848-1939, Tom Steele narrates the development as caused by the formation of a bourgeois public sphere, later a proletarian public sphere, and especially the rise of mass politics and larger popular movements. ${ }^{11}$ Eric Hobsbawm, quoted above, makes a similar observation but inserts organised labour as the key agent in the story. ${ }^{12}$ Swedish research on the development of popular education in the late nineteenth and early twentieth centuries - especially in the hands of the so-called popular movements (folkrörelserna) - has to a large extent followed the same explanatory pattern. ${ }^{13}$

There is no single-cause answer to the question of why popular education embarked on a more stable path from the 1870 s and onwards. Therefore I want to underline that the causal factor I will put forward is one - although in my view an important one - situated in a set of other causal factors. Social forces of collective agency and popular education as a function of a larger history of class politics are necessary and important elements. Strangely, the material economic conditions have seldom been discussed as a crucial mechanism. Still, popular education needed financial security in order to survive. In order to be able to hold courses, the folk high schools needed school houses, furniture, books and writing materials; teachers, heat and wood. And in order to hold lectures for the working classes and the larger public, lecture societies needed currency to pay the public speakers, to pay for material, the rent of the lecture hall, advertisement and to heat up the building they used. How did they get the finances to afford the crucial equipment?

The financing of organisations is often a result of a complex mix of external and internal funding, such as donations and membership fees. Furthermore, the different types of economic input rest on different social forces and conditions. ${ }^{14}$ A precondition for membership fees is the ability of prospective members to actually afford them. In turn, the ability to pay is conditioned the levels of salaries, and also the belief in the goals of the organisation and the spare time which is needed to go to meetings. Accordingly, the material basis of organisations is in turn conditioned by

11 Steele (2007), 1-3, 10,41-43, 53-55. One problem with this explanation is that the phenomena and its explanatory factor are basically two parts of the same event.

12 Hobsbawm (1989), 263.

13 For a discussion of the earlier research on the rise of popular education in Sweden (and popular movements which practiced popular education), see especially the summaries in Samuel Edquist, Nyktra svenskar: Godtemplarrörelsen och den nationella identiteten 1879-1918 (Uppsala: Uppsala universitet, 2001), 26-30; and Samuel Edquist, En folklig historia: Historieskrivningen i studieförbund och hembygdsrörelse (Umeå: Boréa, 2009), 32-36. For the rise of popular movements in Finland, see Henrik Stenius, Frivilligt jämlikt samfällt: Föreningsväsendets utveckling $i$ Finland fram till 1900-talets början, med speciell hänsyn till massorganisationsprincipens genombrott (Helsingfors: Helsingfors universitet, 1987). The importance of the rise of organised labour has been underlined in Inge Johansson, Bildning och klasskamp: Om arbetarbildningens förhistoria, idéer och utveckling (Stockholm: Arbetarnas bildningsförbund, 2002). The role of the ideologies of popular education and their connections to the spread of democracy has been discussed in e.g., Bernt Gustavsson, Bildningens väg: Tre bildningsideal i svensk arbetarrörelse 1880-1930 (Göteborg: Göteborgs universitet, 1991). Sven Lundkvist has underlined the emancipatory function of popular movements and popular education in Folkrörelserna $i$ det svenska samhället 1850-1920 (Uppsala: Uppsala universitet, 1977). On the rise of libraries, and espacially as a part of class formation, see Marion Leffler, Böcker, bildning, makt: Arbetare, borgare och bildningens roll i klassformeringen i Lund och Helsingborg 1860-1901 (Lund: Lunds universitet, 1999).

14 David Knoke, Organizing for Collective Action: The Political Economies of Associations (Hawthorne: A. de Gruyter, 1990), 47-55. 
a range of structural regularities. One such structural factor was, as I will show, the modern industrial state.

The role of the new industrial state has never been identified as a part of the narration and causal historical arguments on the subject. This is problematic due to the fact that the government offered subsidies to the main institutions of the popular educational sphere. Hence, one benefactor of popular education has seldom been acknowledged as an important agent in the overall story. The absence of studies on the role of the state and the economy of popular education is a conundrum since non-governmental organisations and especially social movements' abilities to gather resources has been underlined as crucial in order to secure a stable development. ${ }^{15}$ Furthermore, the research that has commented on the economic foundations or the Swedish state grants directed at for example folk high schools has not studied their impact. ${ }^{16}$

'The state' is however a troublesome concept. Evidently the rise of a continuous popular educational sphere coincided with the formation of a modern style of government - the 'spreading out of the state' - and the second industrial revolution. During the period 1870-1910, and especially from the 1890s and onwards, the economic growth and the states' revenues accelerated. Economic growth was mainly caused by the new areas of productions, such as the chemical and paper industries and the production of engineered and electrical goods. ${ }^{17}$ The nineteenth century capitalist state managed the economy through enabling measures such as subsidies and economic policy-making, for example in form of trade barriers and taxes. Thus, the state enabled and drove the industrial development. ${ }^{18} \mathrm{~A}$ famous Swedish example is the protectionist politics from the late 1880 s, which aimed to protect domestic agricultural production against cheap U.S and Russian grains. The state also managed the population through mass education, social policy and by redistributing taxes. Thus, "effective state craft", as Peter Evans puts it, was important and necessary to secure the economic conditions of industrialisation, as well as the formation of industrial societies. ${ }^{19}$ As Bob Jessop has argued, economic interventions, for instance into the private sector, is a structural preference "built into the capitalist state".

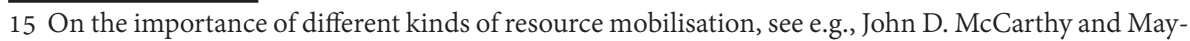
er N. Zald, "Resource Mobilization and Social Movements: A Partial Theory," American Journal of Sociology 82, no. 6 (1977), 1212-241; L. A. Banaszak, Why Movements Succeed or Fail: Opportunity, Culture, and the Struggle for Woman Suffrage (Princeton: Princeton University Press, 1996); Pernilla Jonsson and Silke Neusinger, Gendered Money: Financial Organization in Women's Movements, 1880-1933 (New York: Berghahn Books, 2012), 3-10.

16 These studies have often focused on one or more specific institutions and not the consequences of the state grants system as a whole. See Sven Swensson, "Folkhögskolan och myndigheterna," in Svensk folkhögskola 100 år, 1, ed. Allan Degerman, Eric Tengberg, and Sven Swensson (Stockholm: Liber, 1968); Bo Andersson, Folkbildning i perspektiv (Göteborg: Göteborgs universitet 1980), 25670.

17 Lennart Schön, "The rise of the fiscal state in Sweden, 1800-1914," in Paying for the Liberal State: The Rise of Public Finance in Nineteenth-Century Europe, ed. JL. Cardoso and P. Lains (Cambridge: Cambridge University Press, 2010), 164-65, 180-82.

18 Rolf Torstendahl, Bureaucratisation in Northwestern Europe, 1880-1985: Domination and Governance (London: Routledge, 1991).

19 Peter Evans, Embedded Autonomy: States and Industrial Transformation (Princeton: Princeton University Press, 1995), 5-6.

20 Bob Jessop, State Theory: Putting the Capitalist State in Its Place (Cambridge: Polity, 1990), 185. 
Another way in which the state spread out is connected to the reform of the political system of governance in 1862 and 1866. In 1862 the first steps were taken to the introduction of a decentralised political system in which municipalities (kommuner) would be the basis of local governance. In 1866 the reform of parliament abolished the membership in an estate as grounds for political participation and introduced a franchise system based on income and taxation. ${ }^{21}$ Thus, in the late nineteenth and early twentieth centuries the political government was spatially separated in the central bureaucracy and the local political communities. The state apparatus was made up by a compound of bodies, especially the central bureaucracy but also the state church, the parliament and local political institutions such as the country administrative board (länsstyrelsen), county council (landsting), and municipal assembly (kommunfullmäktige). It should also be noted that during the period 1870-1910s the local institutions of government were perceived as self-governing communities with the responsibility for, among other things, health care and education. Therefore it is important to separate the central bureaucratic apparatus, in this case the Department of Ecclesiastics and Education (Ecklesiastikdepartementet) from the other branches in the analysis of the public sector as a whole. In the following I will refer to the whole apparatus of the political government as 'the state' or 'the public sector', and specify in detail and separate different divisions of it when needed. ${ }^{22}$

In order to analyse the material preconditions and the role of the state in the rise of a continuous popular educational sphere, this article focuses on the size, impact and possible influence of the state grants. I start out by sketching a picture of the state grants-system and which sorts of institutions the economic policies were directed at. In the study I have concentrated on the three largest reforms that launched under the period 1870-1914: the grants to folk high schools in 1872 (and the conjoined scholarship-grants for lesser able students to attend the schools in 1884), the grants for giving lecture courses from 1884, and grants for setting up libraries in 1905. The main sources in this part are the official statutes of the policy programs and earlier research. The Department of Ecclesiastics and Education also supplied grants to universities who held lectures for the public, to editors of certain journals and books, and to groups that supported sobriety. Although these minor grants can be considered as state support for popular education, they are not included in the study due to their trivial size. Also, this limitation makes possible a more thorough analysis of the impact of the three largest reforms. It must be noted that the state by issuing these grants, also demarcated which kinds of educational organisations and practices that should evolve. Study-circles - perhaps one of the most known forms of popular education - did not receive grants until $1947 . .^{23}$

21 Erik Nydahl, I fyrkens tid: Politisk kultur i två ångermanländska landskommuner 1860-1930 (Härnösand: Mittuniversitetet, 2010), 15-20.

22 On this wider concept of 'the state', see the discussion on the liberal state's appearance as a separate central bureaucracy with spatial limitations in James Ferguson and Akhil Gupta "Spatializing States: Toward an Ethnography of Neoliberal Governmentality," American Ethnologist 29, no. 4 (2002), 981-82; Patrick Joyce, The State of Freedom: A Social History of the British State since 1800 (Cambridge: Cambridge University Press, 2013), 25. In economics the public sector is used in order to separate the sphere of the governmental institutions on different levels from the private interests of the business world. This is how the concept is used in this article. On the public-private terminology, see Jonas Harvard, "Historikerna och den osynliga offentligheten," in Dolt i offentligheten: Nya perspektiv på traditionellt källmaterial, ed. Staffan Förhammar, Jonas Harvad and Dag Lindström (Lund: Sekel, 2011), 11.

23 See Samuel Edquists article in this issue. 
After the background I move on to analyse the extent of the public grants and their relationship to the expanding sphere. Firstly, I deal with the development of economic grants, issued by the Department of Ecclesiastics and Education. For this study the official state budget is used. In this section I also use official statistics in order to comment on the growth of the institutions of popular education. Secondly, I analyse the role of public funding for the material conditions of popular education. The basis for this analysis is the part played by public money in relation to the total incomes of folk high schools and agents who offered lectures for workers and the wider public. Here I have utilised audit reports and accountings from a few selected cases. ${ }^{24}$ The bulk of this source material consists of the audit reports that grant-seekers had to send in to the Department of Ecclesiastics and Education with their applications. They are mostly handwritten and signed but some of these reports existed in printed form and was adjoined in the applications. Because the material for the most part was produced for the eyes of the state and used to apply for subsidies it is problematic from the perspective of source criticism. To put it bluntly, there is always a risk that the organisations exaggerated their need for public money by downplaying the share of private funding. Still, the audit reports did go through a lot of checks, such as external accountants and the county councils, before they were sent in, which made cheating, not improbable, but harder to get away with. Also, the annual audit reports in the stack of applications are the largest corpus of this kind of information to be found, and in order to study the organisations which received funding, this is the most effective way to go about it.

The time frame in this study corresponds to the era of history Eric Hobsbawm discussed above - the age of imperialism in which popular education expanded. But there is another argument for ending this study before the First World War. From the early 1910 s and forward, the state started to reform, regulate and integrate popular education into its sphere of governance more thoroughly. To name one example, in the year 1912 the folk high schools' grant-system was reformed. In practice, the government introduced a more deployed system of inspections and surveillance. ${ }^{25}$

\section{The policies and the grants-system}

The folk high school, directed at the self-owning lower-middleclass segments of the agricultural classes, was one of the first examples of popular education becoming an object of economic policy. In 1872 the parliament decided that schools would be offered financial support if they fulfilled certain conditions and the reform was implemented the following year. Ten years later, an additional reform passed, offering the schools a possibility to apply for scholarships for so-called "less fortunate" students. ${ }^{26}$ The three reforms and grants-systems focused in this article were constructed according to the matching grants-principle. Matching grants was a common method used in educational development in nineteenth century Sweden; the public school system

24 I have limited this particular study to focus on folk high schools and lecture-givers. Further limitations, in order to make the large material manageable, are discussed in the sections below.

25 Tomasz Maliszewski, "On the History of Folk High Schools in Sweden," in Folk High School - School for Life, ed. Marek Byczkowski, Tomasz Maliszewski, and Ewa Przybylska (Wiezyca: Wiezyca, 2003), 108-20; Caroline Runesdotter, I otakt med tiden? Folkhögskolorna i ett föränderligt fält (Göteborg: Göteborgs universitet, 2010), 80-81.

26 Swensson (1968), 138-44, 181-84, 200-1; Runesdotter (2010), 57-63. 
was in part financed in this way. ${ }^{27}$ In the case of folk high schools, it was initially prescribed that local backing should count for the majority of the grants, constituting double the amount given by the government. However, this requirement was soon abolished as the stipulated sums were too high. Henceforth private, municipal or county council counter-financing, put together, should match the government's amount. $^{28}$

The next large reform was especially directed at popular education in an urban setting. In 1884, the Swedish parliament decided that the government was going to offer grants to urban institutions and associations which held lecture-courses for the working class. In 1908 the clause regarding the intended audience of the lectures was removed. Henceforth the program was intended for "organisations and institutions which offered lectures on popular science for a popular educational purpose". (In practice it was primary the middle classes that actually visited the lectures.) The ability to apply for lecture-grants was extended to the countryside in $1892 .{ }^{29}$ Finally, in 1905, the last major reform during the period discussed here, offered the possibility to apply for funding for setting up public libraries. This reform was tailored for people living in the countryside as well as the cities, and funding was available for local political institutions as well as voluntary societies and organisations. ${ }^{30}$

State intervention, such as economic policy-programs, hinges on political struggles in the governmental infrastructure. ${ }^{31}$ The economic reforms were originally non-government bills coming from left-liberal members of the second chamber of parliament; many of whom were personally engaged in both popular education and local politics. Thus, even though some of the initiatives can be seen as products of the wider state, in the eyes of the representative's, popular education belonged to the private self-ruling sphere. ${ }^{32}$ In each of the cases the decision to allocate funds was preceded by parliament debates and reports by the State's committee (Statsutskottet). ${ }^{33}$ Generally speaking, the bourgeois liberals and the agricultural interests-groups of the second chamber were in favour of economic backing and the conservative upper class of the first chamber had a more precarious outlook. However, high-ranking

27 Esbjörn Larsson and Johannes Westberg, "Om skolreformers ekonomiska förutsättningar och konsekvenser," in Allt på ett bräde: Stat, ekonomi och bondeoffer: En vänbok till Jan Lindegren, ed. Peter Ericsson, Fredrik Thisner, Patrik Winton, and Andreas Âkerlund (Uppsala: Acta Universitatis Upsaliensis, 2013), 161-68.

28 When subsidies increased sharply in 1912, the demand regarding the matching of grants was further reduced, indicating a deeper financial responsibility taken by the central bureaucracy. From 1878 an additional reform was passed. Schools could get 1,000 SEK extra in grants if they instituted a second year. In 1888, the extra contribution was raised to 3,000 SEK. Swensson (1968), 187-90.

29 Andersson (1980), 256-59.

30 Magnus Torstensson, Att analysera genombrottet för de moderna folkbiblioteksidéerna: Exemplet Sverige och några jämförelser med USA (Göteborg: Göteborgs universitet, 1996), 47-54; Dan Andersson, Folkbibliotek makt och disciplinering: En genealogisk studie av folkbiblioteksområdet under den organiserade moderniteten (Stockholm: Stockholm universitet, 2009), 47-54.

31 Jessop (1990), 186.

32 Runesdotter (2010), 65-67. On the interconnectedness between agents from the private sector, local government and central bureaucracy in nineteenth century Sweden, see Annette Zimmer and Stefan Toepler, "The Subsidized Muse: Government and the Arts in Western Europe and the United States," Journal of Cultural Economics 23, no. 1-2 (1999), 39-40.

33 Valfrid Palmgren, Förslag angående de åtgärder, som från statens sida böra vidtagas för främjande af det allmänna biblioteksväsendet $i$ Sverige (Stockholm: I. Hæggström, 1911), 33-36. 
participants of the first chamber, including the minister of the Department of Ecclesiastics and Education, held that popular education was an essentially good idea. And such support probably helped to get the grants-system passed. ${ }^{34}$

In a larger theoretical perspective, the answer to the question "why state grants?" is that giving subsidies was a new method of state governance. The new industrial state, often called the 'social liberal state', was a state of autonomy. It helped to create autonomous free sectors and exercised power through 'the conduct of conduct'. Instead of working against the formation of voluntary action in civil society, the state started to manage the space of possibilities and steer organisations in a functional direction. In a larger perspective, the policy programs shared ideological traits with other contemporary social policies. Increased popular education was for instance supposed to act as a social remedy. ${ }^{35}$ In official discourses, the society and its population was more and more considered as an integrated national body, where different productive classes was to perform different functions. Education for the nation's working classes would, as commented by Ola Andersson in one of the bills for folk high schools, fuel the industrial development. ${ }^{36}$ Arguments for popular educational was in other words similar to those put forward for the expansion of public schooling for the nations young. ${ }^{37}$ The purpose of this article is not to expand on the arguments for state grants but to estimate their impact. However, generally speaking, the arguments differed between organisations directed at the rural farmer's class, such as the folk high schools, and the lectures for the working class, which were directed at urban milieus. The farmers were supposed to become more industrious and also learn how to act as political subjects in the local government. The workers were to stay away from filthy literature, drinking and other socially dangerous leisure activities. Thus, the case at hand, speaks to how governmental intervention into different segments of the population increasingly became an acceptable solution in order to secure the totality. ${ }^{38}$

The steering of the structure of popular education can for instance be seen in the statutes governing the grants-system. In order to receive funding, the organisations had to fulfil a range of requirements which in all likelihood influenced their behaviour. In every case of grant seeking, the ability to guarantee counter-financing from the local county council was mandatory. This clause in the regulations forced

34 Swensson (1968), 137-42; Anderson (1980), 257.

35 Anne Berg, "The State of Autonomy: The Social Liberal State and the Politics of Financing Non-Formal Education in Sweden c. 1870-1910," Scandinavian Journal of History 40, no. 1 (2015), 48-69.

36 Ola Andersson, Om beviljandet af anslag åt folkhögskolorna, non-government bill no. 160 (1872), Riksdagens protokoll vid lagtima riksmötet. Andra kammaren (Stockholm: Riksdagen, 1867-1948). See also A. Key, Om förhöjning i anslaget till understöd åt anstalter eller föreningar, som anordna föreläsningar för arbetsklassen, non-government bill no. 147 (1886), Riksdagens protokoll vid lagtima riksmötet. Andra kammaren (Stockholm: Riksdagen, 1867-1948); F. Bergs \& E. Hammarlunds, Om statunderstöd till folkbibliotek, non-government no. 90 (1902), Riksdagens protokoll vid lagtima riksmötet. Andra kammaren (Stockholm: Riksdagen, 1867-1948).

37 Fritz Ringer, "On Segmentation in Modern European Educational Systems: The Case of French Secondary Education, 1865-1920," in The Rise of the Modern Educational System: Structural Change and Social Reproduction 1870-1920, ed. Detlef K. Müller, Fritz Ringer, and Brian Simon, (Cambridge: Cambridge University press, 1987), 61.

38 On the discourse of governmental intervention in late nineteenth century Sweden, see e.g., Svenbjörn Kilander, Den nya staten och den gamla: En studie i ideologisk förändring (Uppsala: Uppsala universitet, 1991). 
the institutions to cultivate good relations to the town boards, county council and municipal assembly. Furthermore, the folk high schools and the organisations that offered lectures had to ascribe to certain forms of institutional make-up and allow inspections in order to receive funding. Also, the folk high schools could not hold their terms during sowing and harvest, and public talks could not include political or religious content..$^{39}$ However, what the state wanted to do, and tried to do, through the regulations for funding - and what this tells us about the governmental methods of the state - is a whole other matter than asking if the public funding actually played a part in its very development.

\section{The grants and the growth of popular education}

How much money did the central bureaucracy spend on popular education from 1873-1912, and what can be said about their impact? As illustrated below, state grants to popular education increased steadily during the period. During the period 1873-1912 the official expenditure rose from 3,235 to 621,446 SEK; yet never averaging more than 0,1 percent of the total state budget. ${ }^{40}$ The period stretching from the late 1890 s to early 1910 s saw the largest rise in subsidies. This was a consequence of successive reform work, the emergence of new institutions and the overall growth of the sector.

Figure 1. State grants to popular education 1873-1912 in Swedish Crowns (SEK)

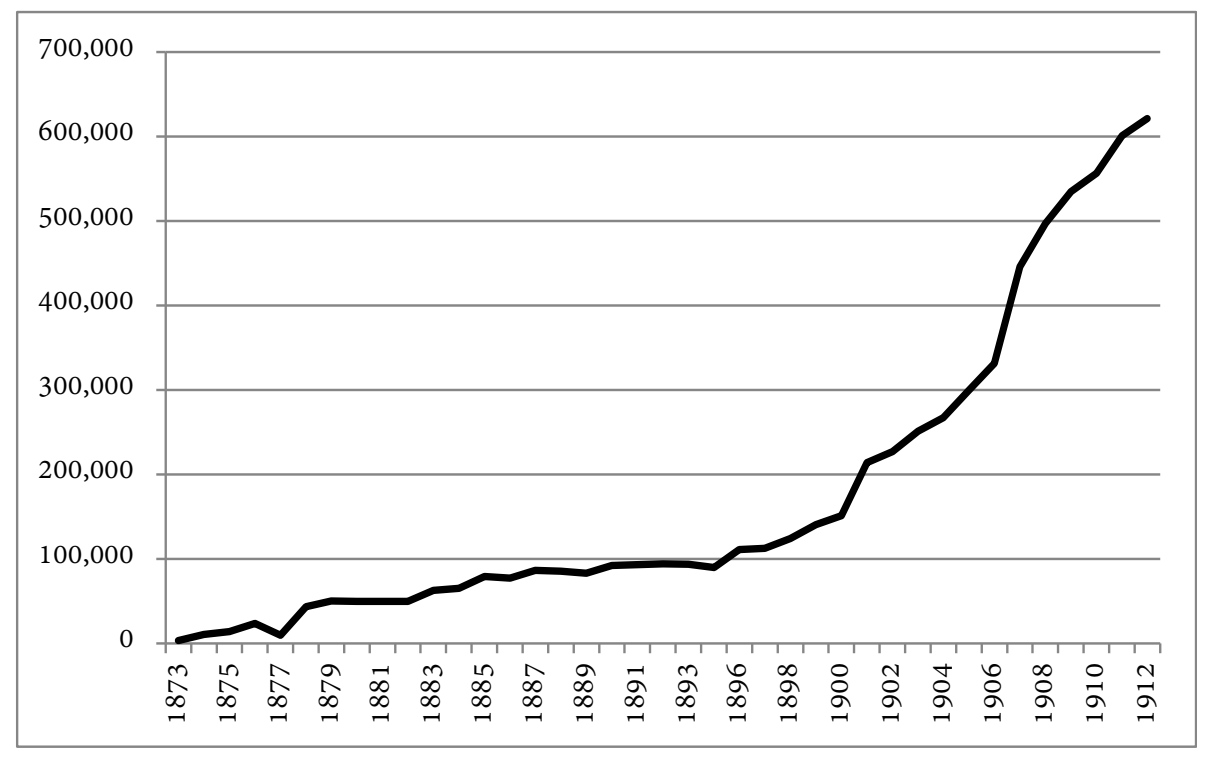

Sources: The data concerning the economic grants to folk high schools and grants for lesser able students, lecture courses and libraries are based on the official economic budget in ch. "Åttonde huvudtiteln," Kapitalkonto för rikshuvudboken (1872-1912). The inflation was low during the period and therefore the expenses are described in nominal value in this article.

39 Berg (2015), 48-69.

40 All the numbers in the text have been rounded off to the nearest integer. 
As I mentioned earlier, the state grants for folk high schools were implemented in 1873. The first proposal for grants set the total sum of assigned funds to 10,000 SEK, and each school could apply for a maximum of 2,000 SEK. The actual expense did however go beyond the apportioned sums - although the first year was an exception - because the number was a proposed sum that could be exceeded. In 1873, the first year of disbursement, only 3,235 SEK were dispensed. On the other hand, only 8 schools of the existing 10 applied for funding. ${ }^{41}$ In the year 1880 the sum elevated to approximately 49,700 SEK, in the year 1901 125,400 SEK and 275,200 SEK in 1912. Additionally, the assigned amount for scholarships to students who could not afford to pay their tuition fees was set at 15,000 SEK in 1884 - the first year of practice. In the year 1912 the amount had risen to 35,000. Also in this case, the largest increases taking place in the end of the 1890s. Statistics from a public inquiry shows that the number of students in the period 1873-1912 was quite extensive. According to estimates, 65,000 young men and women took a course or a few semesters at the schools during these decades. ${ }^{42}$

The idea of private, municipal or county counter-financing, matching the government's amount, was reused in the reforms aimed at lecture courses and libraries. As in the case of folk high schools, the matching grants system meant that local political institutions came to carry the largest burden of counter-financing. According to the first charter regarding the economic aid to lecture courses for workers, 15,000 SEK was set aside in the state budget for 1885 and 14,250 SEK was dispensed. An individual applicant could at most obtain 3,000 SEK and the maximum sum did not change during the studied period. A decade later, the total sum of distributed funds had risen to 23,925 SEK, in 1905 the grants reached a total of 120,300 SEK and in 1912 the total amount of funding was 242,300 SEK. Also in this case, the largest increase in funding occurred in the period from the late 1890 s and forward. The biggest leaps were taken in the period 1902-1909 when the funds grew between 20,000 and 35,000 SEK each year. Furthermore, additional means in the range of 8,000-10,000 SEK was added from 1906 and onwards, which was distributed amongst so-called central offices, which in turn distributed funds to agents giving lectures on a regular basis (even though they were not included in a specific lecture course). As in the previous case, additional reforms after the first one, especially the extension of possible applicants in the early 1890 s, is a clue to the overall picture of a sharp rise in funding in the 1890s and onwards.

Another contributing factor to this picture is that the last big reform was founded in the early 1900s. When the library reform launched in 1905, it stated that two kinds of library organisations could apply for money. The first group consisted of "some kind of public libraries," which addressed applicants from all of the school districts in the country, churches in Stockholm and Gothenburg (for the establishment and maintenance of parish libraries), rural and urban municipalities (for the establishment and maintenance of municipal libraries) and local associations "which stands

41 See the file Nyköpings m. fl. Landshövding, ang. anslag till folkhögskolor. Konseljakter E1A, 187307-18, no. 17, Ecklesiastikdepartementets arkiv [The archive of the Department of Ecclesiastics and Education], at the Swedish National Archives. For numbers of folk high schools, see Swensson (1968), 287-88.

42 Margit Vinge, ed., Elever i icke-obligatoriska skolor 1864-1970 (Stockholm: Statistiska centralbyrån, 1977), 80. 
on equal footing with the school district or municipality". The second group that could apply consisted of "certain key compounds" which "effectively acted as agencies for libraries, such as ambulatory libraries. ${ }^{43} \mathrm{~A}$ sum of 60,000 SEK was appropriated in 1905 and 10,000 SEK of the amount was divided among key compounds; the rest was divided between school districts, townships, municipalities and other institutions. Individual applicants in the first group could receive up to 75 SEK per year. Applicants in the second group could receive up to 1,500 SEK per year. ${ }^{44}$ During the period 1906-12 the appropriated funds lay still at 60,000 SEK per year. Before 1909 the government actually had to reallocate funds for the following year because the number of applicants that met the conditions was too few. But after this year the real expenditure surpassed the granted proposed resources. In the year 1909, 60,085 SEK was dispensed and in 191269,200 was granted to a range of libraries. ${ }^{45}$

Looking at the big picture, the government successively passed new reforms and raised the amounts of economic grants during the period. But did the state grants have any bearing on the formation of a continuous popular educational sphere? Scholars who have studied the government's and municipal's contribution to private preschools and residential industrial schools, has argued that they had a stimulating effect on the development of these kinds of voluntary organisations. Also, in the case of public mass education, state grants functioned as a stimulating factor. ${ }^{46}$ Did the increasing pay-out of state grants from the Department of Ecclesiastics and Education correspond, if all, to the rise of a continuous popular educational sphere? The relationship between increased funding and numerical growth of organisations is not clear cut. To argue that the first caused the second is not possible unless the connection between the two trends can be asserted. It is highly possible that the growth in institutions from below caused the growth of expenses from above. The figures do however suggest that the grants-system at least acted as a stabilising factor - creating the economic possibilities for financial continuity, in tune with other factors.

In line with the modern state's proneness for information-gathering, the development of popular education quickly became a topic of statistical reporting and documentation. ${ }^{47}$ The data was published in Sweden's Official Statistics and Statistical reports. This tells us that the government sought to gather information regarding the benefits and effects of the reforms; and also, using the figures presented, that the organisations experienced stabilisation due to government subsidies. ${ }^{48}$

The folk high schools got so-called proposed funding (förslagsanslag). This meant

43 Svensk författningssamling (Swedish Code of Statues, hence shortened SFS) 1905:29. The rules of the 1905 statutes did not change significantly until the reform of 1912. SFS 1912:229. Bih. 29, 1905, Svensk författningssamling (Stockholm: Svensk författningssamling, 1868-1912).

44 SFS 1905:29.

45 The data concerning the economic grants are based on the official economic budget in Kapitalkonto för rikshuvudboken, ch. "Åttonde huvudtiteln," for the years 1906-1912.

46 Johannes Westberg, "Stimulus or Impediment? The Impact of Matching Grants on the Funding of Elementary Schools in Sweden During the Nineteenth Century," History of Education 41, no. 1 (2013), 1-22.

47 Michel Foucault, Discipline and Punish: The Birth of the Prison (Harmondsworth: Penguin, 1991); Joyce (2013), 162-84.

48 BiSOS: Kungl. Befallningshavandes Femårsberättelser Ny följd IV. Jemte sammandrag för åren 18711875 (1878), 56; BiSOS: Kungl. Befallningshavandes Femårsberättelser Ny följd IIV. Jemte sammandrag för åren 1886-1890, 93-94; "Statsbidrag till föreläsningsföreningar för år 1911", Sociala meddelanden, no. 1-6 (1912), 312-18. 
that the assigned funds could be exceeded. Proposed funding were given to institutions in the ordinary budget (ordinarie stat) when it was hard to account for the real financial need beforehand. For example, the prison system had proposed funding to meet its fluctuating needs. Furthermore, proposed ordinary funding could not be put on hold if the government needed to re-allocate resources.

The case of folk high schools exhibits a pattern of co-variation of increased funding and institutional growth. The majority of the 45 schools founded before 1912 , enjoyed continuity. From 1873 to 1876 the number of schools doubled from 10 to 20. The distributed funds at the same time rose from 3,235 to 23,780 SEK. Although the expenses increased from 23,780 in 1876 to 57,510 in 1900 only an additional 9 schools were established. Thus, the expansion of schools did not grow in tune with the growth in funding; instead it was probably the case that each school got more and more financial aid. On the other hand, only a handful of schools were forced to close. It is highly possible that the funds stabilised and kept the folk high school sector intact, but did not directly stimulate establishment of new schools. Still, it is possible to see a growth in establishment of new schools when the proposed funds grew. During the period 1900-1912 the proposed funds rose from 55,000 SEK to 220,000 SEK. The real expenses were 78,892 and 275,179 SEK respectively. Throughout the years of this large increase in funding, 15 schools were founded, and the total amount of schools was 45 in the year $1912 .{ }^{49}$

Grants for lecture-courses were posted under the extra ordinary budget (extra ordinarie stat). This meant that a decision on granting or not should be made every new budget-year. Thus, the policy was amenable to the wishes of the sitting parliament and could be postponed. However, no postponements took place during the period under study.

The number of grant-taking organisers of lecture courses did not increase much during the first ten years when the proposed funding ranged between 15,000 and 25,000 SEK and the real costs hovered slightly under. This era only saw a small rise from 12 organisations in 1885 to 27 in 1895 . However, from 1895 and onwards (when the appropriated sum was increased by 5,000 each year) a larger movement was formed. Between 1901 and 1905 the number of grants-takers tripled. In 1901 63,336 SEK was distributed among 123 applicants. In 1905 the funding had doubled to 125,000 and 338 organisations received grants. From 1905 to 1910, when the appropriated sum of 125,000 SEK almost doubled to 235,000 SEK (the real expenses was 120,273 and 242,275 SEK) the number of institutions who got funding increased from 338 to $505 .^{50}$

Library grants appear to follow a similar pattern. Grants for public libraries were, in the same way as folk high schools, posted under the title of proposed funding in the ordinary state-budget. The economic reforms for funding of libraries came fairly late in comparison with the other large non-formal educational organisations, thus contributing to the illustrated increase in total funding from the late 1890 s discussed above (see Figure 1). The appropriated funds were set at 60,000 SEK 1906-1912, during the following six years the real expenditure grew from 10,376 to 69,229 SEK.

49 On the number of schools, Swensson (1968), 287-92.

50 "Sammanslutning mellan föreläsningsföreningarna," Svensk läraretidning, no. 44, (1902), 833-834. A list off the recipients for the year 1912 was published in the article "Statsbidrag till föreläsningsföreningarna för år 1911," Statistisk tidskrift , no. 4 (1912), 312-18. 
This rise in real expenses mirrored the growth of library institutions. It is hard to calculate how many so-called private associational libraries (föreningsbibliotek) the state distributed funds to, or the average resources received by a library in the hands of a larger movement such as The Stockholm Society for Workers Libraries. But some figures exist for the years 1906-1908 in an official rapport on the subject. The number of private library institutions that received funding in 1906 was 49. Two years later, the number had risen to $98 .{ }^{51}$ During the same time the total sum of expenses grew from 10,375 to 55,478 SEK. ${ }^{52}$ Because the maximum amount an individual private applicant could ask for lay fixed during the period, it is perhaps not controversial to draw the conclusion that the pattern of gradually increased spending reflected the expansion of the number of associational libraries. It also means that the importance of funding probably varied locally and between different associations.

Due to the financial continuity state grants offered, and the fact that the amounts and the number of grant-takers gradually increased, the indications are that grants helped to stabilise and secure a sphere of popular educational initiatives. Government grants did not make the sector, but they probably secured and stabilised its development. Before the introduction of grants, popular education lived a fairly insecure life. The promise of economic security, and the unceasing expansion of reforms, most likely helped to make the organisations continuous. This argument will be further reinforced in the next section.

\section{The share and significance of public funding}

In order to fully estimate the impact factor public funding had on the stability and continuity of the sphere, an analysis on the grants from both the Department of Ecclesiastics and Education and local governments share of the total budget of the organisations which inhabited the popular educational sphere is called for. In the following I discuss this issue on the basis of a few selected cases of folk high schools and institutions that applied for lecture-grants.

In modern societies, money, rents and property are the most important resources. Before the 1870s, popular educational societies was for the most part dependent on membership fees or donations by individuals or families. A donation could mean giving clean money or instructional materials - books to a thirsty library or maps to empty compound walls. For example, The Society for Diffusion of Useful Knowledge, founded in 1833, partially lived off the interest rates from tenants of the homestead Broddarp bequeathed to the society by the count Trolle-Bonde. However, this particular society was composed of aristocrats, capitalists and educated higher middleclass men, and a donation of this kind was generally not available to the educational associations of the paupers. ${ }^{53}$ For instance, the early educational circles and workers associations mainly financed their activities on membership fees. In their ground-breaking study of the financial system of Swedish women's movements 1880-1933, Pernilla Jonsson and Silke Neusinger concludes that membership fees were the most important and principal source of income. Furthermore, this gave the

\footnotetext{
51 Palmgren (1911), 69.

52 The figures can be found in ch. "Åttonde huvudtiteln," Kapitalkonto för rikshuvudboken (1904, 1906).

$53 \operatorname{Berg}(2011), 204$.
} 
organisations independence from other interests - the government or other agents. But at the same time the cash flow was affected by the economic climate and member's ability to pay. ${ }^{54}$ The Swedish women's movements reliance on membership fees diverges a lot from the folk high schools, libraries and the lecture-societies, mostly composed of workers institutes.

From the early 1870 s to the early 1910 s, the share of public resources in the overall economic foundations of the folk high schools grew massively. Out of the total budget of folk high schools, the share of the public sectors revenue averaged on 17 percent for the years 1871-72. The 17 percent consisted of grants coming from municipalities and county councils. ${ }^{55}$ Forty years later this figure had risen to 74 percent (see Figure 2). If we only consider the state grants coming from the Department of Ecclesiastics and Education - leaving out the grants from local governmental institutions - the figures is not surprisingly 0 percent for the first years of the study (before the grants system was introduced) and averages on 33 percent $1880-1881$ and $44-45$ percent for the following three periods under study.

Figure 2. The percental share of public and private funding of folk high schools, 1871-1911

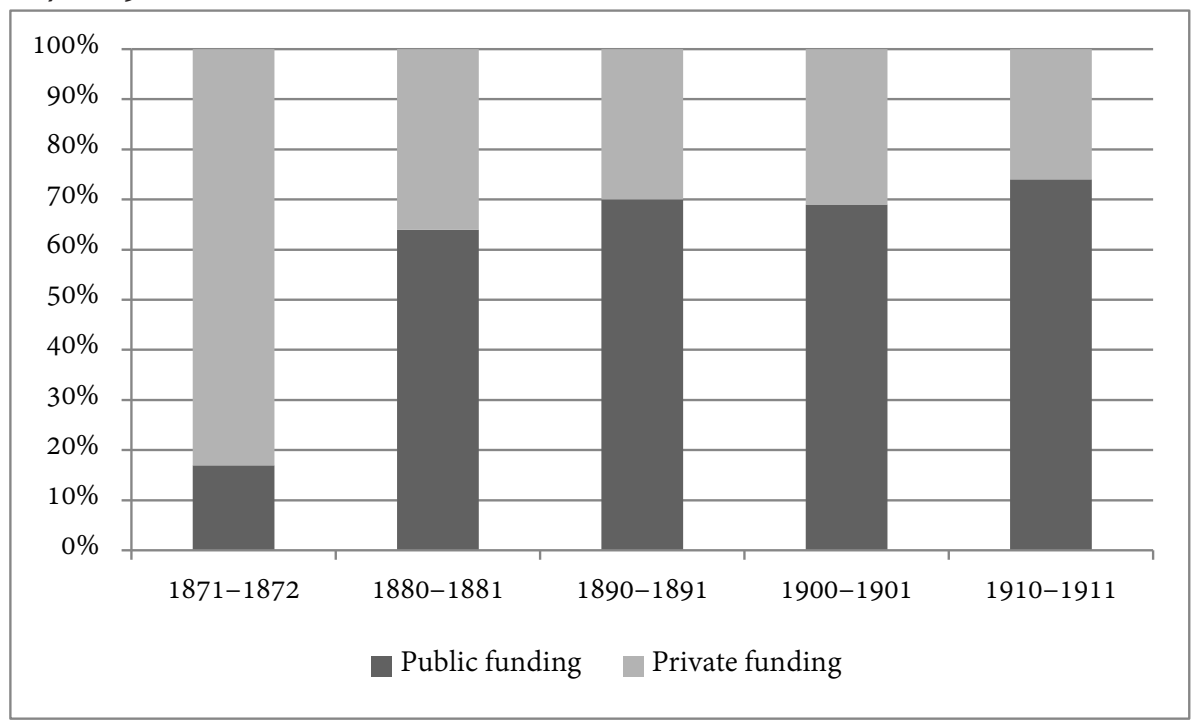

Sources: The figures are based on the declaration of income that folk high schools seeking state grants had to include in their applications. See the applications in the files Nyköpings $\mathrm{m}$. fl. Landshövding, ang. anslag till folkhögskolor. Konseljakter E1A 1875-10-01, n:o 25; Ang. understöd för folkhögskolor för år 1882, Konseljakter E1A 1875-10-01, n:o 21; Ang. fördelning af anslaget till folkhögskolor, Konseljakter E1A 1892-07-01, n:o 26; Ang. anslag till folkhögskolor för år 1902, Konseljakter E1A 1902-0613, n:o 28; Ang. understöd åt folkhögskolor, Konseljakter E1A 1912-06-14, n:o 76. All files are deposed under the Ecklesiastikdepartementets arkiv [The archive of the Department of Ecclesiastics and Education], at the Swedish National Archives.

54 Jonsson and Neusinger (2012), 219-21.

55 I have focused on the share of government grants from the schools' total set of incomes. I have not studied the share in relation to the total set of resources and assets, such as the market value of the school-houses or the inventories. Also I have not taken into consideration the differences in grants directed at courses for women and men respectively. 
The investigation on the share of public funding clearly shows how the grants successively became one of the most important sources of income for folk high schools. Expanding the argument, we can say that the economic material basis of the folk high schools to a large extent was provided by the state apparatus.

Folk high schools have traditionally been regarded as one of the key institutions of the popular educational sphere. Some of the folk high schools were either started by or taken over by county councils during the period 1870-1912 which complicates things. ${ }^{56}$ Thus, in my theoretical perspective, some institutions can be seen as being parts of - or becoming parts of - a larger state apparatus and therefore these schools should probably be funded by public resources to a larger extent. In either way, this pure fact speaks to the role played by the industrial state in the rise of the sphere.

Figure 3. The share of public funding for two folk high schools, 1872-1911

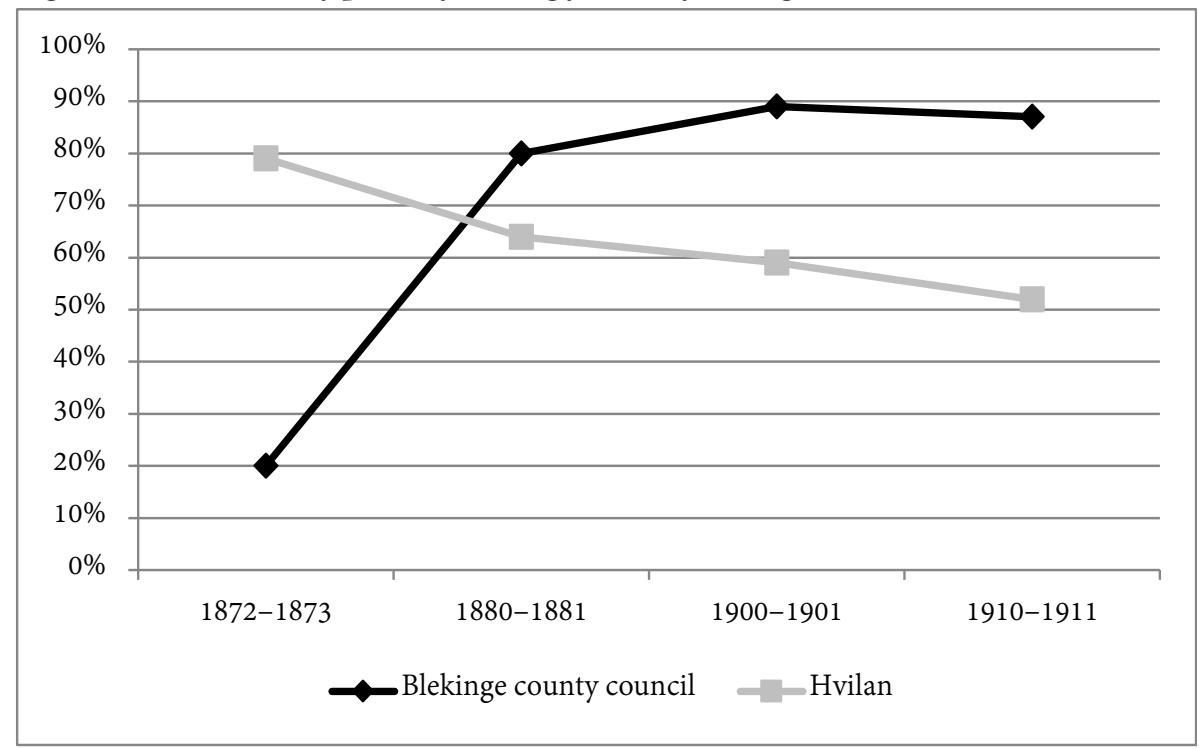

Sources: The figures are based on the declaration of income that Blekinge county council and Hvilan folk high schools included in their applications for state grants. See the applications in the files Nyköpings $\mathrm{m}$. fl. Landshövding, ang. anslag till folkhögskolor. Konseljakter E1A 1875-10-01, no. 25; Ang. understöd för folkhögskolor för år 1882, Konseljakter E1A 1875-10-01, n:o 21; Ang. understöd åt folkhögskolor, Konseljakter E1A 1912-06-14, no. 76. All files are deposed under the Ecklesiastikdepartementets arkiv [The archive of the Department of Ecclesiastics and Education], at the Swedish National Archives. I have left out the years 1900-1901 in this study because there are no figures from Blekinge folk high school for this period.

A study of two of the earliest and long-lived folk high schools of the time, Hvilan (1868) and the Blekinge county council folk high school (1869) reveals that this is the case (see Figure 3). Both of the schools started out as rural projects with a folk high school association in the background. Hvilan never became owned by the county council, which was the destiny of many folk high schools. The folk high schools which started in all corners of Sweden between the years 1880 and 1900 were all

56 Anna Lundin, Folkbildningsforskning som fält: Från framväxt till konsolidering (Linköping: Linköpings universitet, 2008), 104-5, 166-67; Runesdotter (2010), 65-67. 
founded by county councils. ${ }^{57}$ Blekinge county folk high school was started by men who were engaged in the folk high school movement at large and in local politics. In this case the chieftaincy lay in the hands of the county council from the very beginning. As mentioned earlier, there was a strong connection between engagement in the folk high school cause and rural politics. Rural politics was to a large extent dominated by rich farmers - the folk high schools chief target group. Hence, many of the farmers who became parliamentarians during the early twentieth century had been former folk high school students. ${ }^{58}$

The privately owned Hvilan started out with a very high percentage of public funding. Gradually this source of income became less important, still never being less than 52 percent of the total revenues in 1910-11. At this later stage the majority of the incomes came from student's fees. The school in Blekinge, on the other hand, only got 20 percent of their livelihood from public institutions in the early 1870 . But in the 1880 s and forward the public funding became the dominant source of income for the school, peaking at 89 percent in 1900-1901 and 87 percent in 1910-11 (see Figure 3). Yet, setting the differences aside, public funding was an important part of the material preconditions for all folk high schools during the period. And taking this fact into account, the funding from the public institutions was probably an important reason to the preservation of new schools.

The organisations which received grants for holding lectures for the working class and the wider public was workers institutes, sections of the workers movements and a range of so called lecture-societies. As mentioned earlier, the amount of grant-takers increased enormously during the period of study. Therefore I have done a sample study of the institutions which applied for grants the year 1890 and the year 1912. The focus, as in the former example, is to assess the part played by the state in securing the organisations economic livelihood.

In 1890 there were only seven applicants, mainly from Stockholm, Gothenburg and Malmö - some of the largest cities in Sweden at the time. The year 1912 the figure had risen to 505. The conclusions drawn on comparisons between the general amount of economic income coming from public means and private means over time are therefore rather trivial. In order to get a more manageable number of applicants for the later date, I have chosen to study the organisations which sent in their applicants to the county administrative board in the small province of Halland. Located in the southern part of Sweden, Halland was however only one of 21 Swedish counties at the time. Yet, the applicants from Halland consisted of the characteristic blend of workers institutes and lecture-societies. Also, the average amount of grant-takers per county 1912 was 21 institutions. The number of applicants in Halland 1912 was 24. This tells us that Halland did not stand out in this account, and that the county is as good as any other in this regard.

57 Runesdotter (2010), 66-67.

58 Maliszewski (2003), 112-13. 
Figure 4. The share of public and private funding for lectures 1890-1891 and 1910-1911

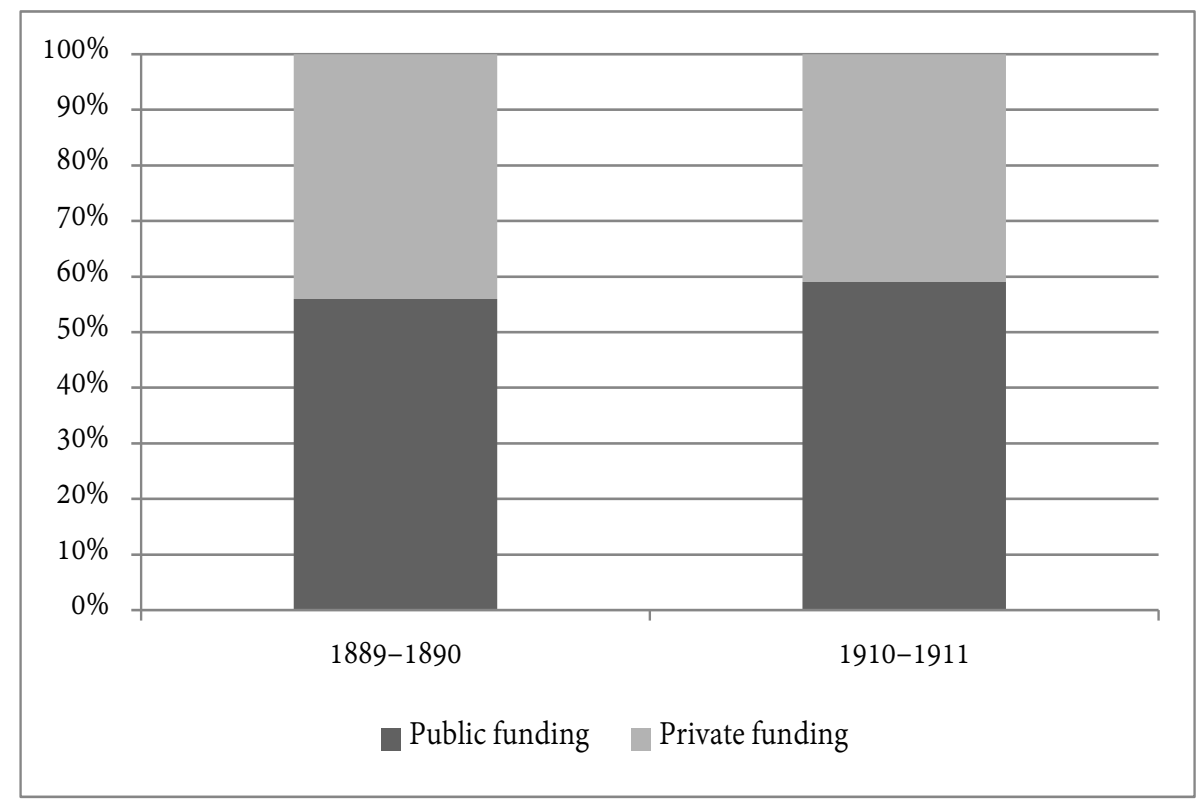

Sources: The figures are based on the declaration of income from organisations seeking state grants, which they had to include in their applications. See the applications in the files Ang. fördelning af anslaget för år 1891 till föreläsningar för arbetsklassen, Konseljakten 1890-12-19, no. 25, E1A, Ecklesiastikdepartementets arkiv, Swedish National Archives; Ang. understöd till anordnande af populärvetenskapliga föreläsningar. [Västerås and Halland county] Konseljsakten 1912-02-02 (file no. 58, Västerås and Halland county), E1A, Ecklesiastikdepartementets arkiv, Swedish National Archives.

The economic incomes for applicants the year 1890 consisted both of public and private resources. The average means from the public sector, the state and the town councils, was 56 percent. The grants from the Department of Ecclesiastics and Education averaged on 40 percent of the total amount of public funding. To illustrate: The Workers Institute of Stockholm had a total income of 14,491 SEK the budget year of 1889 , of which the amount 8,000 SEK consisted of public funding: 5,000 SEK from the town council and 3,000 SEK from the government. Remaining resources came from private sources such as membership fees and entrance charges..$^{59}$

On the other hand I must mention that the average percentage of public funding actually misrepresent the total economic situations of the grant-takers for the budget year 1890-91. The fact is that the overall pattern is that different institutions solely survived on public funding while others took very little if any at all. For example, 96 percent of the total income of The Workers Institute in Gothenburg consisted of public funding, while only 6 percent of The Stockholm Burghers Schools budget came from public grants. ${ }^{60}$

59 See the application act for The Workers Institute of Stockholm in Ang. fördelning af anslaget för år 1891 till föreläsningar för arbetsklassen, Konseljakten 1890-12-19, no. 25, E1A, Ecklesiastikdepartementets arkiv, Swedish National Archives.

60 See the application files for The Workers Institute in Gothenburg and The Stockholm Burghers Schools in Ang. fördelning af anslaget för år 1891 till föreläsningar för arbetsklassen, Konseljakten 1890-1219, no. 25, E1A, Ecklesiastikdepartementets arkiv, Swedish National Archives. 
The figures for the economic budgets of the grant seekers from Halland in 191112 are much more consistent and reliable. Still, on average, a similar figure of 58 percent was the amount coming from public funding of some sorts. The rest of the resources came from membership fees and the entrance charges. In rare occasions, the majority of the private assets came from business corporations. In the small town of Oskarström in Halland, the local sulphite corporation (Oskarströms Sulfitaktiebolag) and textile industry (Skandinaviska Jute Spinneri \& Väveri AB) accounted for 43 percent of the total set of incomes for the Oskarström lecture-society for the budget year $1911 .{ }^{61}$ As in the case of the early mass educational system, the capitalist class sometimes funded educational initiatives. ${ }^{62}$

Generally, the societies and organisations that applied for lecture-grants probably needed these grants to stay alive. The case study shows that public funding - state grants as well as city or county council grants - composed nearly 60 percent of the total revenue. The specific grants coming from the Department of Ecclesiastics and Education averaged on 26 percent $1890-91$ and had risen to 37 percent of the total incomes for the years 1910-11. I shall not wander into the area of contra-factual history, yet as many as 500 plus organisations would probably not have enjoyed the same stability and continuity without public funding. ${ }^{63}$ The share of public funding was over half of the incomes of the lecture societies from the 1890s to the 1910s. As in the case of folk high schools, the state's role in securing the economic preconditions for the organisations was vital.

\section{Conclusion}

During the long nineteenth century the middle and working classes of Europe started to engage in popular education, especially in class-based associations. They taught themselves how to practice democracy, learned about civic and social issues, improved their civic conduct and also learned practical skills. Popular education in the form of workers institutes, public libraries and lecture-societies spread all over Sweden from the 1870 s and onwards. The organisations were characterised by being well-organised and enjoying continuity as well as pure numerical growth. Before the 1870s, popular education was characterised by being discontinuous. Organisations was fairly few and did not survive especially long due to state repression, fluctuating membership numbers and a low level of national organisation. Thus, the period between the early 1870 s and the First World War saw the rise of a continuous popular educational sphere.

Why did this historical process occur? The existing international and Swedish research has to a large extent, and rightfully so, focused on class politics and class struggle as the chief explanatory mechanisms. However, organisational continuity

61 Application for Oskarström, Ang. understöd till anordnande af populärvetenskapliga föreläsningar. [Västerås and Halland county] Konseljsakten 1912-02-02 (file no. 58, Västerås and Halland county), E1A, Ecklesiastikdepartementets arkiv, Riksarkivet Marieberg.

62 Madeleine Michaëlssons analysis on the role of iron companies as contributors to school funding in ironwork communities supports this claim. Madeleine Michaëlsson, "From Tree Felling to Silver Lining: Diverse Ways of Funding Elementary Schools among Swedish Ironworking Communities, 1830-1930", in History of Schooling: Politics and Local Practice, ed. Carla Aubry \& Johannes Westberg (Frankfurt am Main: Peter Lang, 2012), 55-58, 66-67.

63 "Statsbidrag till föreläsningsföreningarna för år 1911," Statistisk tidskrift, no. 4 (1912), 312-18. 
does to some extent rest on the ability to secure a steady flow of economic resources. In this article I show how another structural regularity of industrialisation, namely the actions of the new industrial state, must be introduced as an important factor in the historical explanation. Theoretically, 'the state' is given a wide definition in this article. It is synonymous with the public arena - the apparatuses of government on a local as well as central level.

The first analysis in the article centred on the total amount of grants that were paid out from the Department of Ecclesiastics and Education. The investigation on the three largest economic reforms directed at popular education during the period - grants for folk high schools (1873), popular lectures (1884) and libraries (1905) clearly shows that the total amount of grants from the Department of Ecclesiastics and Education increased during the period, as did the number of popular educational organisations that was sponsored. Thus it is probable that the two observable processes influenced each other. Folk high schools, organisations that offered lectures and founded libraries received state funding if they could get matching grants from the local political institutions or a compatible private interest. Further evidence that points in this direction is the fact that the state grants system integrated popular education in a system that secured a part of their finances, as long as the applicants followed the rules. After it was in place, it is plausible that the system worked as a stabilising factor.

A case study of the public funding's share of the total incomes of folk high schools and lecture societies in the southern province of Halland, further speaks to the new role of the state in creating the fruitful material pre-conditions for 'the rise'. In order to evaluate the role and impact of the state grants, I used both official economic data from the government, official statistics and audit reports from organisations that applied for grants. Public funding answered for at least half of the lecture-societies budgets. In the case of folk high schools, the majority of the economic incomes came from the public sector - from grants given by the Department of Ecclesiastics and Education, the county council and the municipalities. The case study shows that this was true both in the case of privately owned schools and the schools that were controlled by the county councils.

What do these results say about the rise of a continuous popular educational sphere in Sweden? I would argue that one has to incorporate the economic and enabling powers of the new industrial state apparatus into the causal narrative. Well, at least in the case of Sweden. I would also argue that too much weight has been laid on the explanatory mechanism adherent to the social consequences of industrialisation in previous research. ${ }^{64}$ The rise of a modern class system and popular education as a method of popular politics was, as scholars such as Tom Steele has emphasised, necessary components in the overall explanation. ${ }^{65}$ But the results in this article suggest that it was the combination of that momentous political force Eric J. Hobsbawm titled "the new working-class movements" engaged in class formation, a middle class seeking to capitalise on its hunger for education and the economic resources bestowed by the modern industrial state, that were the main conditions for the rise of

64 See generally, Lundkvist (1977); Leffler (1999); Johansson (2002); Hobsbawm (1989), 263; Steele (2011), 1-3, 10, 41-43, 53-55

65 Steele (2011), 1-3, 10, 41-43, 53-55. 
a continuous popular educational sphere in Sweden. ${ }^{66}$

However, in order to fully answer this question more investigations into the material conditions of popular education are necessary. We need more case studies on the share and impact of public resources from different local environments. In this article, the case of Halland was chosen because it had an averaging number of organisations, and that the province has left behind a convenient amount of sources. But how did the share and significance of public funding vary between different social and cultural milieus? Would, for instance, a consistent investigation of urban milieus give us another answer? These are questions left to be answered.

$\overline{66 \text { Hobsbawm (1989) }}, 263$. 


\section{References}

\section{Archival sources}

Riksarkivet, Stockholm [Swedish National Archives]

Ecklesiastikdepartementets arkiv.

\section{Printed sources}

Bidrag till Sveriges officiella statistik: Kungl. Befallningshavandes Femårsberättelser Ny följd IV. Jemte sammandrag för åren 1871-1875 (1878) (BiSOS).

Bidrag till Sveriges officiella statistik: Kungl. Befallningshavandes Femårsberättelser Ny följd IIV. Jemte sammandrag för åren 1886-1890 (BiSOS).

Kapital-konto till riks-hufvud-boken för år ... med dertill hörande tablåer och bilagor. Stockholm: Riksdagen, 1872-1912.

Riksdagens protokoll vid lagtima riksmötet. Andra kammaren. Stockholm: Riksdagen, 1867-1948.

Sociala meddelanden.

Statistisk tidskrift.

Svensk Författningssamling (SFS) [laws and ordinances].

Svensk läraretidning.

\section{Literature}

Amnizade, Ronald. Ballots and Barricades: Class Formation and Republican Politics in France, 1830-1871. Princeton: Princeton University Press, 1993.

Andersson Bo. Folkbildning i perspektiv. Göteborg: Göteborgs universitet, 1980.

Andersson, Bo. Folkbibliotek makt och disciplinering: En genealogisk studie av folkbiblioteksområdet under den organiserade moderniteten. Stockholm: Stockholms universitet, 2009).

Banaszak, L. A. Why Movements Succeed or Fail: Opportunity, Culture, and the Struggle for Woman Suffrage. Princeton: Princeton University Press, 1996.

Berg, Anne. Kampen om befolkningen: den svenska nationsformeringens utveckling och sociopolitiska förutsättningar ca 1780-1860. Uppsala: Uppsala universitet, 2011.

Berg, Anne. "The State of Autonomy: The Social Liberal State and the Politics of Financing Non-Formal Education in Sweden c. 1870-1910." Scandinavian Journal of History 40, no. 1 (2015), 48-69.

Edquist, Samuel. En folklig historia: Historieskrivningen i studieförbund och hembygdsrörelse. Umeå: Boréa, 2009.

Edquist, Samuel. Nyktra svenskar: Godtemplarrörelsen och den nationella identiteten 1879-1918. Uppsala: Uppsala universitet, 2001.

Evans, Peter. Embedded Autonomy: States and Industrial Transformation. Princeton: Princeton University Press, 1995.

Ferguson, James and Akhil Gupta. "Spatializing States: Toward an Ethnography of Neoliberal Governmentality." American Ethnologist 29, no. 4 (2002), 981-1002.

Foucault, Michel. Discipline and Punish: The Birth of the Prison. Harmondsworth: Penguin, 1991.

Giddens, Anthony. The Consequences of Modernity. Stanford: Stanford University Press, 1990. 
Gustavsson, Bernt. Bildningens väg: Tre bildningsideal i svensk arbetarrörelse 18801930. Göteborg: Göteborgs universitet, 1991.

Harvard, Jonas. "Historikerna och den osynliga offentligheten." In Dolt $i$ offentligheten: Nya perspektiv på traditionellt källmaterial, edited by Staffan Förhammar, Jonas Harvad \& Dag Lindström, 9-18. Lund: Sekel, 2011.

Hobsbawm, Eric. The Age of Empire 1875-1914. New York: Vintage Books, 1989.

Hroch, Miroslav. Social Preconditions of National Revival in Europe: A Comparative Analysis of the Social Composition of Patriotic Groups among the Smaller European Nations. New York: Columbia University Press, 2000 [1985].

Jenkins, J. Craig. "Resource Mobilization Theory and the Study of Social Movements." Annual Review of Sociology 9 (1983), 527-553.

Jessop, Bob. State Theory: Putting the Capitalist State in Its Place. Cambridge: Polity, 1990.

Johansson, Inge. Bildning och klasskamp: Om arbetarbildningens förhistoria, idéer och utveckling. Stockholm: Arbetarnas bildningsförbund, 2002.

Jonsson, Pernilla and Silke Neusinger. Gendered Money: Financial Organization in Women's Movements, 1880-1933. New York: Berghahn Books, 2012.

Joyce, Patrick. The State of Freedom: A Social History of the British State since 1800. Cambridge: Cambridge University Press, 2013.

Kilander, Svenbjörn. Den nya staten och den gamla: En studie i ideologisk förändring. Uppsala: Uppsala universitet, 1991.

Knoke, David. Organizing for Collective Action: The Political Economies of Associations. Hawthorne: A. de Gruyter, 1990.

Larsson, Esbjörn and Johannes Westberg. "Om skolreformers ekonomiska förutsättningar och konsekvenser." In Allt på ett bräde: Stat, ekonomi och bondeoffer: En vänbok till Jan Lindegren, edited by Peter Ericsson, Fredrik Thisner, Patrik Winton, and Andreas Åkerlund, 157-179. Uppsala: Acta Universitatis Upsaliensis, 2013.

Leffler, Marion. Böcker, bildning, makt: Arbetare, borgare och bildningens roll $i$ klassformeringen i Lund och Helsingborg 1860-1901. Lund: Lunds universitet, 1999.

Lundin, Anna. Folkbildningsforskning som fält: Från framväxt till konsolidering. Linköping: Linköpings universitet, 2008.

Lundkvist, Sven. Folkrörelserna i det svenska samhället 1850-1920 (Uppsala: Uppsala universitet, 1977.

Maliszewski, Tomasz. "On the History of Folk High Schools in Sweden.” In Folk High School - School for Life, edited by Marek Byczkowski, Tomasz Maliszewski, and Ewa Przybylska, 108-120. Wieżyca: Kaszubski Uniwersytet Ludowy, 2003.

McCarthy, John D. and Mayer N. Zald. "Resource Mobilization and Social Movements: A Partial Theory," American Journal of Sociology 82, no.6 (1977), 1212241.

Michaëlsson, Madeleine. "From Tree Felling to Silver Lining: Diverse Ways of Funding Elementary Schools among Swedish Ironworking Communities, 18301930." In History of Schooling: Politics and Local Practice, edited by Carla Aubry and Johannes Westberg, 38-67. Frankfurt am Main: Peter Lang, 2012.

Nydahl, Erik. I fyrkens tid: Politisk kultur i två ångermanländska landskommuner 1860-1930. Härnösand: Mittuniversitetet, 2010. 
Palmgren, Valfrid. Förslag angående de åtgärder, som från statens sida böra vidtagas för främjande af det allmänna biblioteksväsendet $i$ Sverige. Stockholm: I. Hæggström, 1911.

Petterson, Lars. Frihet, jämlikhet, egendom och Bentham: Utvecklingslinjer i svensk folkundervisning mellan feodalism och kapitalism, 1809-1860. Uppsala: Uppsala universitet, 1992.

Ringer, Fritz. " On Segmentation in Modern European Educational Systems: The Case of French Secondary Education, 1865-1920." In The Rise of the Modern Educational System: Structural Change and Social Reproduction 1870-1920, edited by Detlef K. Müller, Fritz Ringer, and Brian Simon. Cambridge: Cambridge University Press, 1987.

Runesdotter, Caroline. I otakt med tiden? Folkhögskolorna i ett föränderligt fält. Göteborg: Göteborgs universitet, 2010.

Schön, Lennart, "The Rise of the Fiscal State in Sweden, 1800-1914." In Paying for the Liberal State: The Rise of Public Finance in Nineteenth-Century Europe, edited by JL. Cardoso and P. Lains, 162-185. Cambridge: Cambridge University Press, 2010.

Steele, Tom. Knowledge is Power! The Rise and Fall of European Popular Educational Movements, 1848-1939. Bern: Peter Lang, 2007.

Stenius, Henrik. Frivilligt jämlikt samfällt: Föreningsväsendets utveckling i Finland fram till 1900-talets början, med speciell hänsyn till massorganisationsprincipens genombrott. Helsingfors: Helsingfors universitet, 1987.

Swensson, Sven. "Folkhögskolan och myndigheterna." In Svensk folkhögskola 100 år, 1, edited by Allan Degerman, Eric Tengberg, and Sven Swensson, 135-283. Stockholm: Liber, 1968.

Torstendahl, Rolf. Bureaucratisation in Northwestern Europe, 1880-1985: Domination and Governance. London: Routledge, 1991.

Torstensson, Magnus. Att analysera genombrottet för de moderna folkbiblioteksidéerna: Exemplet Sverige och några jämförelser med USA. Göteborg: Göteborgs universitet, 1996.

Vernon, James. Politics and the People: A Study in English Political Culture, c. 18151867. Cambridge: Cambridge University Press, 1993.

Westberg, Johannes. "Stimulus or Impediment? The Impact of Matching Grants on the Funding of Elementary Schools in Sweden during the Nineteenth Century." History of Education 41, no. 1 (2013), 1-22.

Vinge, Margit. ed., Elever i icke-obligatoriska skolor 1864-1970. Stockholm: Statistiska centralbyrån, 1977.

Zimmer, Annette and Stefan Toepler. "The Subsidized Muse: Government and the Arts in Western Europe and the United States." Journal of Cultural Economics 23, no. 1-2 (1999), 33-49. 